\title{
"A white city of desolation": Verdun as seen by three British nurses
}

Sylvie Pomiès-Maréchal

\section{(2) OpenEdition}

1 Journals

\section{Electronic version}

URL: http://journals.openedition.org/rfcb/294

DOI: $10.4000 / \mathrm{rfcb} .294$

ISSN: 2429-4373

\section{Publisher}

CRECIB - Centre de recherche et d'études en civilisation britannique

\section{Printed version}

Date of publication: 15 January 2015

ISSN: 0248-9015

\section{Electronic reference}

Sylvie Pomiès-Maréchal, " "A white city of desolation": Verdun as seen by three British nurses », Revue Française de Civilisation Britannique [Online], XX-1 | 2015, Online since 01 May 2015, connection on 30 April 2019. URL : http://journals.openedition.org/rfcb/294 ; DOI : 10.4000/rfcb.294

This text was automatically generated on 30 April 2019.

\section{(c) $(1)$}

Revue française de civilisation britannique est mis à disposition selon les termes de la licence Creative Commons Attribution - Pas d'Utilisation Commerciale - Pas de Modification 4.0 International. 


\title{
"A white city of desolation": Verdun as seen by three British nurses
}

\author{
Sylvie Pomiès-Maréchal
}

At a time when social expectations firmly confined women to the domestic sphere and war propaganda extolled maternal duties, ${ }^{1}$ only a small number of women went close to the firing lines. Individuals' relation to war was then highly gendered, with set mental and cultural representations. Most women remained on the home front while men were enjoined to serve their country. ${ }^{2}$ Within the armed forces, the only suitable female role was that of military auxiliary with the taking up of logistic jobs releasing men from menial though strategic tasks. Another exception was participation into auxiliary medical organisations, as nursing tended to be regarded as an extension of the domestic sphere; celebrated feminine values such as caring and nurturing roles established an implicit connection between nursing and domestic ethics. This paper focuses on the experience of British nurses, drawing on the personal accounts of Kathleen Burke, Winifred Kenyon and S.M. Edwards, three British women involved in what became one of the most dreadful battles of the Western front, the Battle of Verdun. 


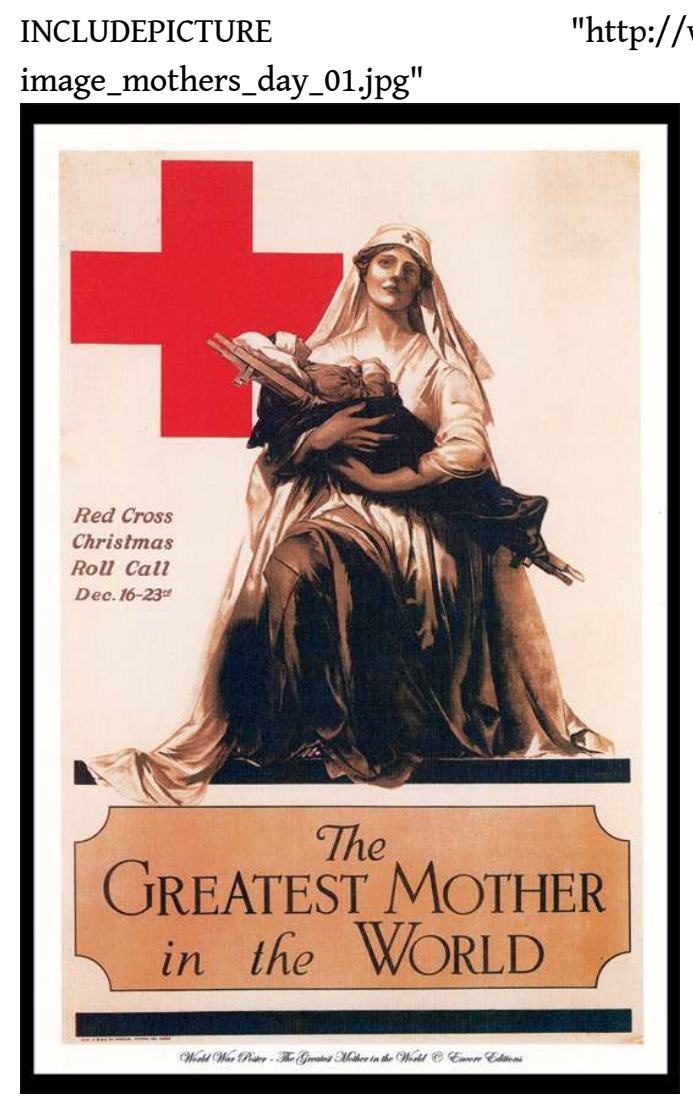

2 Though acting at different levels of responsibility, these young volunteers went through converging experiences. Trying to put down in words this unspeakable reality, their eyewitness accounts echo one another. As a nurse posted behind the Verdun front, Winifred Kenyon witnessed the onset of the Great Push while Kathleen Burke offered a forceful description of the citadel. This paper will first address military and historical aspects as developed by Kenyon and Burke. It will then explore the human dimension of these accounts reflecting on the significance of early $20^{\text {th }}$ century social representations as well as wartime expectations. The nurses' focus on compassion and their strategic role in sustaining life, alleviating pain and "containing trauma" ${ }^{3}$ will also be developed.

\section{Biographical background and nature of the sources}

There is unfortunately very little biographical background concerning these British nurses but the few elements we have indicate that they came from the upper class. Winifred Kenyon was born in January 1892, the third daughter of Major-General Edward R. Kenyon. Shortly after her $23^{\text {rd }}$ birthday, she joined the Voluntary Aid Detachment ${ }^{4}$ and went to France as a cook for a mobile field unit between the base hospital and the firing line. Her private diary has never been published and mainly deals with her experience at Bar-Le-Duc and later as a VAD nurse from June 1915 to June 1917 at the "Urgency Cases Hospital", Le Faux Miroir near Révigny sur Ornain (Meuse). ${ }^{5}$ Miss Edwards worked in the same hospital and left a moving and compassionate account of her experience, "Thoughts of a Night Sister", published in Le Faux Miroir, the magazine of the "Urgency Cases Hospital". A copy can be found in Miss Kenyon's personal file at the Imperial War Museum. The author's very identity remains enigmatic as the two-page article is signed "SME" but a photograph of the nursing staff included in the magazine identifies her as S. 
M. Edwards. There is no literature concerning these accounts. Kathleen Burke's White Road to Verdun ${ }^{6}$ was published in 1916 but there is very little literature on the author and none on her narrative. Kathleen Burke was born in London in October 1887. When the First World War broke out, this 27-year-old suffragist signed up as a Red Cross nurse. ${ }^{7}$ In May 1915, she joined the Scottish Women Hospitals, a nursing organization entirely conceived, run and operated by women. ${ }^{8}$ Within the organisation, Kathleen Burke acted as a spokeswoman and was responsible for raising funds. In July 1916, as organising secretary of the SWH, she was sent on a special mission to France and Belgium where she visited the trenches and the local units of the SWH. She was the first woman to enter Verdun during the great siege in the summer of 1916, and she met General Petain. Additional biographical elements related to Miss Burke mainly deal with her philanthropic work as "godmother » of the French martyr village of Maillé, until her death in $1958 .^{9}$

4 The writings considered in this paper are thus different in nature. They are intended for different audiences and serve different purposes: Miss Kenyon's diary was never meant to be read by anyone but herself while, right from the start, Miss Burke's account was intended for publication. Miss Edward's writing was also written with publication in mind though it aimed at a much more limited readership, namely the staff and patients of the "Urgency Cases Hospital" at Le Faux Miroir. Materials published during the war are bound to be tinged with patriotism, if not propaganda. Censorship, whether official ${ }^{10}$ or self-imposed, must also be taken into account. However, these writings are anchored in everyday experience and as first-hand narratives, provide revealing insights into their authors' perceptions of the war.

\section{Military developments as witnessed by Kathleen Burke and Winifred Kenyon}

Kathleen Burke's prose is primarily driven by patriotism. She first gives details on war machinery and mentions behind the lines training camps where soldiers, the "gallant sons of Gaul", were taught trench-fighting and practised the throwing of hand grenades in mock trenches. As far as medical novelties are concerned, Miss Burke provides information on the first X-ray cars for which she organised demonstrations, together with Marie Curie. ${ }^{11}$ She also describes the cars fitted with bath tubs for the troops or those fitted as moving dental hospitals.

6 Indeed, the First World War was a catalyst in the field of medical research with many surgical innovations and technical developments such as blood transfusion which had first been developed in the 19th century but had fallen into disuse. The Carrel-Dakin technique, an antiseptic treatment for the dressing of wounds, is another innovation of World War One. ${ }^{12}$ Nurses were mainly responsible for implementing these new techniques but occasionally, they could also take on the work of surgeons and could perform minor surgery such as the extraction of shrapnel from wounds. ${ }^{13}$

7 By contrast to Miss Burke's narrative, Miss Kenyon's diary starts in quite a light-hearted way, reflecting her enthusiasm and expectations. She hardly ever mentions the war, writes about the glorious spring of 1915, her relations with other VADs, how they played basketball in their spare time and how "extraordinary one [could] feel at peace in spite of everything." Upon arriving in Bar-le-Duc in March 1915, she says: 
Bar-le-Duc is quite a large town and doesn't seem to have suffered in any way from bombardment, though we've been told there's hardly a house left between this and the front. And here I come to a very sore point. We are 30 miles from the firing line and, up to now, have hardly ever heard the guns. ${ }^{14}$

8 At the onset of the war, this spirit was quite common among the young keen volunteers who embarked on an "adventure of a lifetime", willing to "do their bits". For these upperclass women, war represented an opportunity to move beyond traditional gendered roles and to release themselves from patriarchal authority. The liberating factor of the Great War appears quite clearly in the writings of women like Enid Bagnold, Mary Borden, Rebecca West or Vera Brittain. ${ }^{15}$

However enthusiastic young VADs could be when signing up, it did not take long for them to come face to face with reality. As the reading of Winifred Kenyon's diary proceeds, one is struck by the drastic change in tone. In May 1915, she moved as a VAD nurse to theatre work which she found "much preferable to kitchen work - far easier, though a great deal is very dull."16 The "Urgency Cases Hospital" was the only British Unit in the Meuse. In January 1915, Miss E. L. C. Eden, Honorary Secretary of the British Union of Trained Nurses had offered to raise for the French government "an English mobile surgical ambulance, complete in all its details, with personnel, equipment and automobiles." ${ }^{17}$ It had a free hand concerning the treatment of the wounded but, as an individual unit, was subject to the regulations of the French Army and was jointly run by British and French medical staff. At first, most of its patients came from the Argonne and most suffered from gas gangrene. In July 1915, the fighting on the Argonne front was not very severe, but occasionally the "Urgency Cases Hospital" offered its services to ambulances of the first line and relieved the pressure of work on the hospital at Les Islettes. ${ }^{18}$

Generally speaking, nurses posted on the Western front mainly had to deal with wounds contaminated with mud and as a result, with tetanus or sepsis. They also had to handle the devastating consequences of new wartime technologies : first and foremost mutilated bodies, but also soldiers suffering from the effects of mustard gas on their lungs or eyes. ${ }^{19}$ Though Kenyon's writing gets grimmer, her tone remains quite factual, almost detached :

June 25: another strenuous day; at one time this afternoon, I felt that I couldn't go on any longer and that I couldn't anyhow stand the theatre. For we had another man to have his thigh amputated today and he died just as they were finishing. And operating till 3.30 this afternoon, that was interesting though, as part was trepanning. But it meant no time off again. ${ }^{20}$

11 This matter-of-fact tone might surprise but one has to bear in mind the high level of "self-containment" required as exposure to shattered male bodies could pose threats to the nurses' own physical and mental safety. Besides, for the patient's sake, they had to hold back their emotions and avoid giving way to negative feelings. According to Christine Hallett, a historian of First World War nursing, "being with a severely mutilated and psychologically distressed patient and showing neither horror nor fear took some practice." 21

Kenyon's comment on the trepanning also illustrates the fascination that many VADs expressed at medical techniques in their diaries. VADs were untrained nurses learning the trade on the job. They were taught by trained nurses and their lack of know-how was sometimes frowned upon by medical staff, leading to strained relationships between volunteer and qualified nurses, though this does not appear in Winifred Kenyon's diary. Edith Appleton's war diaries provide a professional nurse's view on VADs. On November 29, 1915, she writes: 
The VADs are a source of great interest to me, they are a splendid bunch. They may be roughly divided into four sorts; "Stalkers", "Crawlers", the irresponsible "Butterflyers" and the sturdy "Pushers". [...] When I show her [a "Butterfly"] how to do anything fresh, she twitches to get at it and says "Oh do let me try - I'd love to do that - simply love to." She's an aristocratic little person, most dainty and well groomed, and the thought of her doing scrubbing and dusting all day makes me smile ${ }^{22}$.

As implied in the last sentence, the tensions that could arise were sometimes intensified by social class differences. Most VADs came from the upper classes and took on nursing as voluntary work whereas for qualified nurses coming from lower classes, nursing was a waged occupation. Moreover, many qualified nurses rightly suspected that VADs might compete unfairly with them after the war. ${ }^{23}$

Signing up as a volunteer nurse working in casualty clearing stations or field hospitals obviously meant exposing oneself to the perils of war. Although hospitals were supposed to be protected by the Geneva Convention ${ }^{24}$, nurses could find themselves in the direct line of fire. From mid-February 1916, as all civilians were evacuated from Verdun, rumours of a German attack grew and orders were received to clear the hospital. Kenyon describes a ward "bristling with excitement" and "[awaiting] events with impatience." ${ }^{25} \mathrm{~A}$ few days later, on the $21^{\text {st }}$ of February 1916, a first air raid was aimed at the hospital. Strategic junctions for Verdun like Revigny, Bar-le-Duc and St Dizier were also bombed by a fleet of aeroplanes as Germans unsuccessfully attempted to cut the railway and other lines of communication to Verdun. Here is a description of the advancing fleet:

I missed hearing the bomb but we think one was intended for the chateau, as it fell in the field just the other side of the road in front of us, and there is nothing else here that it could have been aimed at. [...] In the afternoon we played basketball, and were all hard at it when one exclaimed "Here they come again". And there we saw, coming up like a fleet, first three, then seven aeroplanes [...] then we saw yet three more, and finally 14 . The guns began again, and they scattered - we heard explosion after explosion as they dropped bombs [...] It was thrilling to watch ${ }^{26}$.

The following night, a Zeppelin which had been flying at an exceptionally low altitude was brought down by two guns over Brabant le Roi. Right from the start, Winifred Kenyon knows she's living through a historic moment. On February $29^{\text {th }}$, she describes the massively destructive industrial warfare which is taking place:

The biggest battle ever known is going on now. We guessed that an attack on Verdun was planned, as the fact that the Germans tried to cut the railway all pointed to it. Now we know. There has been the most tremendous attack conceivable, huge guns first, blowing everything to pieces, and men beyond all count. At first it seemed that the Germans were getting the best of it, the French to fall back a bit, all trenches on both sides were blown to pieces, the losses in men were enormous, the Germans of course suffering most, and they say that their bodies are lying in heaps. ${ }^{27}$

Whether this was really the case or some form of collective self-delusion meant to sustain morale is difficult to assess. W. L. Kenyon's main source of information came from her French patients and, in any event, this report and the ones that follow reflect the soldiers' immediate perceptions of the conflict. On that particular occasion, though both sides suffered massive losses, the Germans do appear to have taken heavier blows. On February $28^{\text {th }}$, out of the 3,500 German soldiers put into action in Douaumont, about 2,000 had died or had been wounded, with German eye-witnesses describing German combatants falling over "like tin soldiers". ${ }^{28}$ 
Then started a nerve-wracking time for everyone. The attack on Verdun developed fast and waves of wounded men began to flow in. For the medical staff, the first priority consisted in appraising the importance of the injuries and sorting out the wounded for treatment. To cope with the rush of work, extra beds were put up, up to a total of 120 beds. Miss Kenyon did not write in her diary for ten days, overstrained by the workload, subordinating her own needs to those of her patients and spending whole nights in the theatre:

The work here is terrible. Such wounds and a great many cases of gas gangrene and in spite of amputations, we have had a lot of deaths. It is simply awful, for the number of wounded is impossible to cope with and they lie unattended to for days and there are no hospitals nearer than Bar, as Clermont has been shelled. ${ }^{29}$

Yet, in the midst of chaos, reports from the front sparked a glimmer of hope as to an impending victory. Far from imagining the war continuing for another two years and a half, Miss Kenyon reports:

The French soldiers who come in are all extraordinarily cheerful, more so than they have ever been before, in spite of the fearful time they have been having. They all say it's Germany's last effort [...]. Never has there been such an exciting time, and never has the end of the war seemed nearer. Oh that it might end, for these last 10 days have made us realize the ghastliness of it as we never did before. ${ }^{30}$

In March, hopes were still high:

The battle of Verdun is still going on, but people are now pretty confident that it will never be taken. The Germans have been simply throwing their men away, while the French haven't called up their reserves at all. The German credit is rapidly going down, while the French has gone up. ${ }^{31}$

Then towards the end of July, cheerfulness started to subside: "[...] Still no signs of a general break up, it's appalling to think of another winter of it, but if something doesn't happen soon, there seems little chance of anything else." W. Kenyon further reported Allied advances. She also mentioned a visit from Pétain: "Then yesterday who should pay us a visit but General Pétain himself, the famous Pétain, Commander of Verdun for some time, now one of the highest French commanders. There's an honour for a little English hospital!"32

Kathleen Burke's account also centres on her experience in Verdun, an experience which likewise, culminated in her meeting with General Pétain and the visit of the citadel. For Kathleen Burke, Pétain is the epitome of might and bravery and is a symbol of conquering France. Similarly, Verdun stands as a symbol of fortitude and glory:

It would be useless to pretend that one entered Verdun without emotion. Verdun, sorely stricken, yet living, kept alive by the indomitable soul of the soldiers of France, whilst her wounds are daily treated and healed by the skill of her Generals. A white city of desolation, scorched and battered, yet the brightest jewel in the crown of France's glory; a shining example to the world of the triumph of human resistance and the courage of men. ${ }^{33}$

Kathleen Burke depicts Verdun as a city of wretchedness where the sounds of innocence like the voices of children and the singing of birds have been replaced by the "cruel sounds " of war. The winter months had been marked by massive bombardments in Verdun and its surrounding areas. It has been estimated that from the start of the German offensive on 21 February up till mid-July, shells fell with a frequency of 115 a minute. ${ }^{34}$ As Burke proceeds through the ruined streets of the citadel, she mentions that everything has remained as in a state of suspension with, in the houses where the front had been blown away, spoons and forks still laid on the table, as if set ready for the next meal. 


\section{Wartime expectations, gender and early $20^{\text {th }}$ century social representations} Christine Hallett: they know that nearly all their comrades merit them." ${ }^{39}$ self-control was everything." ${ }^{\text {"0 }}$

Beyond the military aspects and tales of destruction, these accounts offer a female perspective on the war, with a particular focus on compassion that reflects the feminine moral code of the period. Just as social expectations equated masculinity with bravery, women were expected to feel compassion. However genuine this compassion must have been (the very nature of the work they had taken on required empathy), the values of sympathy and benevolence were ingrained in the feminine ethics of the upper class. For

it was not the reality of nursing but its distorted public image that drew VADs into nursing work. The propaganda of the "angel of mercy" who would bring humanity and compassion to the battlefield led them to believe that a caring heart and a passion for involvement was all that was required to make a good military nurse. ${ }^{35}$

Paradoxically, through the notions of courage and sacrifice, this compassion which found its expression in women's commitment to the war effort also went hand in hand with the endorsement of war itself. For Janet Lee, "During the war, traditionally gendered maternal scripts provided overriding metaphors for women's role since patriotic duty was linked to women's work as mothers cheerfully sending sons off to war and maintaining domestic constancy." 36

This aspect is particularly significant in Kathleen Burke's writing. Her portrayal of both Poilus and Tommies, of their patriotism and sense of sacrifice casts light on the prevalence of this trope. While Miss Kenyon describes wounded French soldiers as "plucky Frenchmen ", Kathleen Burke draws a colourful portrait of the Poilu, highlighting his "quickwittedness", his "strange irony and cynical wit". Another feature of the French soldier is his " bitter and biting humour" when speaking of the enemy. ${ }^{37}$ The opening lines of her narrative actually start by a description of the Poilu spirit and mentality exemplified by his motto that whatever may happen, one has to accept one's fate as long as it serves the grandeur and the People of France. "Ne pas s'en faire", such is the motto which comes back like a litany throughout the text, correlated with the "willing sacrifice" of the soldier who took up arms to "offer his body as a shield to defend the Heart of France."

Thus, a recurring theme in Kathleen Burke's account is the glorification of the soldier. Surprisingly enough, this exaltation goes hand in hand with the ordinariness of everyday heroism: "Every man is really a hero, and the men who have medals are almost ashamed, since

This stress on fortitude, grandeur, and stoicism reveals the high value attached to the ethics of self-discipline in the first decades of the twentieth century and, tellingly, many nurses' diaries reveal similar perceptions of the soldier:

Reaching back to a time when the "stiff upper lip" was an attractive feature - a virtue - requires the twenty first century audience to suspend its own prejudices and hear the voices of the past without distortion [...] The world of the Great War military nurse was one in which combatants were both "boys" and "heroes", and

Nevertheless, whether this work was government-sponsored ${ }^{41}$ or not, the publication of the book was commissioned by the Scottish Women's Hospitals and considering the author's mission, Kathleen Burke's heroic style may also be regarded as a form of 
propaganda aimed at striking a patriotic chord in order to raise funds. As Peter Buitenhuis writes:

The conventional trope of motherhood is of care and nurture. In the Great War, 1914-1918, the trope underwent a major shift to dictate that mothers should willingly sacrifice their sons for the sake of an Allied victory. [...] The official perversion of maternal nurturing was one of the greatest successes of Great War propaganda and it is clearly reflected in the fiction of the period. ${ }^{42}$

Through the allegorical figure of "Mother France", the closing lines of The White Road to Verdun offer a striking illustration of the "perversion" of motherhood and of this trope of sacrifice and self-denial :

The men owe much their courage to the attitude of the women who stand behind them, turning their tears to smile to urge their men to even greater deeds of heroism. [...] Because these women of France have sent their men forth to die, eyes dry, with stiff lips and head erect, do not think that they do not mourn for them. When night casts her kindly mantle of darkness over all, when they are hidden from the eyes of the world, it is then that the proud heads droop and are bent upon their arms, as the women cry out in the bitterness of their souls for the men who have gone from them. Yet they realise that behind them stands the greatest mother of all, Mother France who sees coming towards her, from all frontiers, line on line of ambulances with their burden of suffering humanity, yet watches along other routes her sons going forth in thousands, laughter in their eyes, songs on their lips, ready and willing to die for her. France draws around her tattered and bloodstained robe, yet what matters the outer raiment? Behind it shines forth her glorious, exultant soul, and she lifts up her head rejoicing and proclaims to the world that when she appealed, man, woman, and child-the whole of the French nation-answered to her Call. ${ }^{43}$

Kathleen Burke praises the "gratitude and perfect discipline" of the wounded soldiers of France. She also celebrates the empathy and the fellowship born of common hardships. Once again, she does so in a highly romantic style with the image of the "chivalrous knight

" based on prevailing ideals of heroism and on the spirit of comradeship"4:

Through the ordeal of blood and fire, each one of them has won his spurs and come out a chivalrous knight, and they bring their chivalry right into the hospitals with them. We [the nurses] had also learned to love them for their kindness to one another. [...] The convalescent sits by the bedside of his new comrade, holding the man's hand whilst his wounds are being dressed, telling him he knows of the pain that he, too, has suffered, and that soon all will be well. ${ }^{45}$

Throughout the account, there is an omnipresent spirit of brotherliness and sharing. Kathleen Burke thus mentions the "magic language of sympathy" ${ }^{46}$ which enables some form of understanding between patients and nurses. Although they could not experience directly the dread of combat, nurses could apprehend what soldiers had endured and while doctors came and went, nurses remained with the wounded in the wards for quite long shifts, developing strong bonds with their patients.

\section{Focus on empathy and the domestic image of nursing work}

While the role reversal induced by the war could have led to a radical transgression of traditional gender roles (in hospital wards, nurses were in a position of power and authority while male patients were in a situation of dependence), conventional gender relations remained quite unshaken. The self-effacement of nurses in their writings, from 
the marginalisation of their role to the idealization of "the boys", indicates that they tended to perceive the war as an exclusively masculine sphere. The "magic language of sympathy" and the nurse's inconspicuousness appear significantly in S. M. Edwards's "Thoughts of a Night Sister", an account published in Le Faux Miroir, the magazine compiled and produced by the French and English staff and patients at the 'Urgency Cases Hospital' in January $1917 .{ }^{47}$ In this writing, we learn very little about the author. The article is only signed by the initials SME. We don't even know her first name as the writer hides herself behind the generic name of "Sister" and refers to herself as "she". Yet, in an indirect way, she reveals herself, pondering on her role, her domestic presence and, with a sense of helplessness, on the meaning or the meaninglessness of the war:

The Surgeon has done his last round, and with a cheery "Good-night", is gone. Sister stands at the door of the ward [...]. She passes from bed to bed, giving a drink here, smoothing a tossed pillow there, tucking up as she would a child - for is not the heart of the "poilu" as the heart of a child? - some brave fellow who has just been through the grim horrors of those hideous slopes on which for nine months the battle of Verdun has raged. [...] She hears the muttered, half-broken sentences of the men as they toss and turn in their restless sleep, and she thinks of the sons of France lying there suffering "pour la Patrie". She thinks of $n^{\circ} 20$, sturdy Breton from far off Brittany, his face rugged like the rugged rocks of the coast on which he has weathered many a storm. Now he has weathered his last and most terrible storm, the storm of battle. [...] She thinks of $n^{\circ} 12$, who has come from the heights of Savoie. Frightfully crippled he lies there, for the deadly gas gangrene has done its fearful work, and never again will he climb his beautiful mountains. He stands on the threshold of life only. "Oh! C'est triste la guerre" - that is all they say, these men. A wonderful spirit, the spirit of France. Yes, it is many of her sons that are gathered here; [...] she thinks of the men who, away in the firing line, where terror and desolation reign, are veritably passing through hell. [...] She hears the rumble of heavily laden trains, as they pass, without ceasing, up to the front with their load of men and ammunition, to be hurled against the might of Germany. [...]

The wind is rising and she hears it sighing in the pines, and it is as if it were the Voix des Morts pleading for their sacrifice not to be forgotten, and she thinks of those brave men - and they are many - who have passed through those pines to their last resting place. She thinks of the little wooden crosses she sees everywhere in this sad corner of France - in the fields, in the woods, in the gardens - and she asks, Is it in vain they have died?

Beyond the numbers is the will to treat patients not so much as cases but as individuals. As implied in the metaphor of the mother tucking up her child, this perception of the nurse's mission is totally in line with the Nightingale legacy where the nurse stands as a source of comfort and stability in the midst of chaos. According to Christine Hallett, the mother figure nurses took on seems to have been as much the product of "instinct" as socialisation:

Trained nurses do not appear to have taken on a stern parenting role deliberately, as a matter of "policy". They seem rather to have instinctively adopted a "mothering" role - acculturated to it during their years of training. They even referred to their patients as "the boys". It is all too easy to criticize this apparent infantilisation of patients living under hospital regimes. Yet, the nurses and patients of the First World War military hospitals appear to have seen it as a natural and necessary condition of safe healing. ${ }^{48}$

Indeed, beyond shattered bodies and physical trauma, nurses had to heal shattered minds and cope with the psychic impact of trench warfare. With soldiers suffering from shell shock, the medical staff primarily had to hold bodies and minds together. While keeping a professional distance, nurses almost took on the role of surrogate mothers or elder sisters 
and were crucial in creating an environment fostering a sense of security and peace. Part of this therapy consisted in giving some kind of domestic varnish to hospital wards, nurses spending their time off decorating them with flowers or bringing gramophones to entertain their patients. Christmas represented a major event as illustrated in Miss Kenyon's description of the 1916 Christmas celebrations:

Jane, Simpie and I were waiting and I wore white, she with a red belt, and I with red ribbon in my hair - a great success. Awful moment when we found the plum puddings had been forgotten and we dashed round and they were hot in time, and carried into a pitch dark room, all ablaze, amidst great applause. ${ }^{49}$

For men who had been estranged from their families for long periods of time, nurses belonged to the sphere of normality and domesticity. They however maintained emotional involvement within the safe boundaries of substitute family members:

Nurses used "familial" relationships with patients to provide comfort while at the same time avoiding the possible dangers of crossing emotional and relational boundaries. They maintained the nurse-patient relationship within the bounds of what was acceptable; and appear to have seen it as part of their duty to avoid both cold clinical professionalism and romantic attachment..$^{50}$

The stress on propriety and the asexual nature of this relationship is clearly implied in Commander-in-Chief Katharine Furse's letter to VAD recruits: "Remember that the honour of the V.A.D. organization depends on your individual conduct. It will be your duty not only to set an example of discipline and perfect steadiness of character, but also to maintain the most courteous relations with those whom you are helping in this great struggle."

In practice, romances could however develop when nurses were off-duty and the nursepatient bond could occasionally shift to a woman-soldier relationship. ${ }^{52}$

Through their gift for narration and their forceful accounts, K. Burke, S.M. Edwards and W.L. Kenyon provided a first-hand approach to the battle of Verdun, putting the individual at the core of their stories. Like many other women, they responded to a powerful urge to help and mostly worked behind the scenes under trying conditions. The nature of these narratives unfortunately did not allow for a longitudinal analysis of their feelings and experiences over time. Miss Burke's writing only covered the summer of 1916. Miss Edward's article was a snapshot of her feelings at the time of publication. In Miss Kenyon's case, the recording of military developments tends to indicate changes in the perception of the conflict but as the war progressed, she put aside her diary and briefly resumed her writing only towards the end of the war.

Moreover, though these accounts tend to converge, writing for an audience and writing for oneself suggest different approaches to events and relate to the public and private dimensions. Miss Kenyon's diary offers a sense of immediacy with an informal and uncensored recording of events as they occurred. In contrast, published materials imply more distancing and a selection of images and events. Whether internalized or relayed, potential interpretations or even distortion may occur, all the more so if they serve propaganda purposes.

In any case, these narratives are anchored in early $20^{\text {th }}$ century reality and indicate how conventional discourses on femininity and masculinity could influence the writers' views on the war and how little traditional gender roles were affected. Nurses de facto brought relief, stood as confidants, handled pain and provided comfort for the dying. By ensuring some semblance of domesticity, they were crucial in bringing a sense of humanity after the dehumanising experience soldiers had gone through. The particular focus on empathy and the sister/mother figure nurses took on are quite revealing. Just as 
significant is the impact of wartime patriotism and propaganda as women's concept of femininity was intrumentalized in order that they might willingly sacrifice their husbands and sons.

\section{BIBLIOGRAPHY}

BURKE, Kathleen. The White Road to Verdun. London: Hodder \& Stoughton, 1916, 138 p., digitized by the Internet Archive / Canadian libraries, http://www.archive.org/details/ whiteroadverdun00burkuoft [Last accessed 20 May 2014] and on the Project Gutenberg website, http://www.gutenberg.org/1/6/9/4/16945, [Last accessed 20 May 2014].

COWEN, Ruth (ed.). War Diaries, a Nurse at the Front, The First World War Diaries of Sister Edith Appleton. London: Simon \& Schuster, 2012, 320 p.

J.A.C.F. [presumably Chief Medical Officer Cairns Forsyth], “A Short History of the Urgency Cases Hospital”, pp. 11-15, Le Faux Miroir, January 1917. W.L. Kenyon’s personal papers.

KENYON Winifred Lilian's private papers, documents.374, catalogue date 1990-05, Imperial War Museum

EDWARDS S. M., “Thoughts of a Night Sister”, pp. 17-18, Le Faux Miroir, January 1917. WL Kenyon's private papers, documents.374, catalogue date 1990-05, Imperial War Museum

DE NAVARRO Antonio, The Scottish Women's Hospital at the French Abbey of Royaumont. London: George Allen and Unwin, first published in 1917, 223 p., digitized in 2007 by the InternetArchive, https://archive.org/details/scottishwomensho00navauoft, [Last accessed 23 May 2014].

Women Brave Guns to Nurse Wounded", New York Times, 2 April 1916, http:// query.nytimes.com/mem/archive-free/pdf?res=F70F10FC3A5812738DDDAB0894DC405B868DF1D3 , [Last accessed 20 May 2014].

FURSE Katharine, B.R.C.S., letter from the Commandant-in-Chief, Women's Voluntary Aid Detachment, to serving VAD nurses (1914), http://www.spartacus.schoolnet.co.uk/ FWWnurses.htm, [Last accessed 23 May 2014].

\section{Secondary sources:}

BOWMAN, Gerald. The Lamp and the Book: the Story of the Rcn, 1916-1966. London: Queen Ann P., 1967, 206 p.

BRAYBON, Gail. Women Workers in the First World War. London: Routledge, 1981, 244 p.

BRAYBON, G. \& SUMMERFIELD, P. Out of the Cage: Women's Experiences in Two World Wars. London: Pandora, 1987, $352 \mathrm{p}$.

BRULEY, Sue. Women in Britain since 1900. Basingstoke: Palgrave Macmillan, 1999, 227 p. 
BUITENHUIS, Peter. "Motherhood Perverted: The Trope of the Son at the Front", pp. 13-23 in A. USANDIZAGA \& A. MONNICKENDAM (ed.), Dressing up for war: transformations of gender and genre in the discourse and literature of war, Amsterdam: Rodopi, 2001, $292 \mathrm{p}$.

COHEN, A., GILMAN, S., BORDO, J. \& SMITH, R. On European Ground. Chicago: Chicago University Press, 2001, $131 \mathrm{p}$.

COHEN, Debra Rae. Remapping the home front: locating citizenship in British women's Great War fiction. Boston: Boston Northeastern University Press, 2002, 548 p.

CULL, N. J., CULBERT, D \& WELCH, D. Propaganda and Mass Persuasion: a Historical Encyclopedia, 1500 to the present. Santa Barbara: ABC-Clio, 2003, $479 \mathrm{p}$.

HALLETT, Christine. Containing trauma, Nursing Work in the First World War. Cultural History of Modern War Series, Manchester: Manchester University Press, 2011.

HOLMES, Katie. « Day Mothers, Night Sisters: World War One Nurses and Sexuality », pp. 42-59 in J. DAMOUSI \& M. LAKE (ed.), Gender and War: Australians at war in the Twentieth Century, Cambridge: Cambridge University Press, 1995, 351 p.

LEE, Janet. War Girls: The First Aid Nursing Yeomanry in the First World War. Manchester: Manchester University Press, 2005, 269 p.

Mc CALLUM, Jack Edward. Military Medicine: From Ancient Times to the 21st Century. Santa Barbara: Abc-Clio, 2008, $383 \mathrm{p}$.

POWELL, Anne. Women in the War Zone, Hospital Service in the First World War. Stroud: The History Press, 2013, 416 p.

TUCKER, S. (ed.). The European Powers in the First World War: An Encyclopedia. London: Routledge, $1999,783 \mathrm{p}$.

\section{Websites}

CHEVEREAU, Sébastien. Dossier de presse "De Santa Barbara à Maillé", Maison du souvenir de Maillé, maison-du-souvenir@maille.fr, http://www.cndp.fr/crdp-orleans-tours/images/stories/CDDP37/dossier\%20de\%20presse\% 20hale.pdf, [Last accessed 23 May 2014].

WALKERS, Julian. "The silence after the war", The British Library, http://www.bl.uk/world-warone/articles/the-silence-after-the-war, [Last accessed 30 May 2014]

Convention for the Amelioration of the Wounded in Armies in the Field (22 August 1864). International Committee of the Red Cross, http://www.icrc.org/applic/ihl/ihl.nsf/ ART/120-40001?OpenDocument, [Last accessed 30 May 2014].

" In Memory of Bravery and Sacrifice », Surgeons' News, The Royal College of Surgeons of Edinburgh, 01 July 2010, http://www.surgeonsnews.com/spectrum/charities/in-memory-ofbravery-and-sacrifice, [Last accessed 23 May 2014].

http://www.wereldoorlog1418.nl/battleverdun/battleverdun22/index.htm, [Last accessed 23 May 2014].

http://eng.verdun.fr/Universal-city/Verdun-and-World-War-I/The-Battle-of-Verdun, [Last accessed 23 May 2014] 


\section{NOTES}

1. War propaganda often blended maternal and religious references. A famous Red Cross poster by Alonzo Earl Foringer (The Greatest Mother in the World) appropriates the image of the pieta with a nurse cradling a wounded soldier. Debra Rae COHEN, Remapping the home front: locating citizenship in British women's Great War fiction, Boston: Boston Northeastern University Press, 2002, p. 81.

See also Peter BUITENHUIS, "Motherhood Perverted: The Trope of the Son at the Front", in A. USANDIZAGA \& A. MONNICKENDAM (ed.), Dressing up for war: transformations of gender and genre in the discourse and literature of war, Amsterdam: Rodopi, 2001, p. 13.

2. The term «Home Front " was first used during the First World War to refer to the civilian population who contributed to the war effort to support the "military front». In all lines of business, women's participation in the waged labour market rose very sharply. Working-class women mostly worked as «munitionettes » while middle and upper-class women mostly took on voluntary work serving in the Red Cross or joining female organizations such as the Voluntary Aid Detachment. For upper-class women, work represented an unprecedented and truly liberating experience.

For a thorough analysis of women workers in Britain during the war, see G. BRAYBON \& P. SUMMERFIELD, Out of the Cage: Women's Experiences in Two World Wars, London: Pandora, 1987, 352 p. and Gail BRAYBON, Women Workers in the First World War, London: Routledge, 1981, 244 p.

3. This expression is borrowed from the title of the book by Christine Hallett: Christine E. HALLETT, Containing trauma, Nursing Work in the First World War, Cultural History of Modern War Series, Manchester: Manchester University Press, 2011, 259 p.

4. 23 was the minimum age for enrolment in the Voluntary Aid Detachment, an organization established in 1909 under the aegis of the Red Cross and the Order of St John. It was founded by Katharine Furse. From 1915 on, "VADs" were accepted on the frontline. They mostly came from the upper middle-class or the aristocracy and had received basic first aid and nursing training. During the course of the First World War, more than 90,000 women served as VADs (Ruth COWEN (ed.), War Diaries, a Nurse at the Front, The First World War Diaries of Sister Edith Appleton, London: Simon \& Schuster, 2012, p. 300).

5. The manuscript diary (149 p.) and its transcript (60 p.) can be found at the Imperial War Museum: Winifred Lilian Kenyon's private papers, documents.374, catalogue date 1990-05, Imperial War Museum.

6. Kathleen BURKE, The White Road to Verdun, London: Hodder \& Stoughton, 1916, 138 p., digitized by the Internet Archive / Canadian libraries, http://www.archive.org/details/ whiteroadverdunooburkuoft [Last accessed 20 May 2014] and on the Project Gutenberg website, http://www.gutenberg.org/1/6/9/4/16945, [Last accessed 20 May 2014].

7. "Women Brave Guns to Nurse Wounded", New York Times, 2 April 1916. http:// query.nytimes.com/mem/archive-free/pdf?res=F70F10FC3A5812738DDDAB0894DC405B868DF1D3 , [Last accessed 20 May 2014].

Though both suffragists and suffragettes had espoused a pacifist stance, at the outbreak of the war, the women's suffrage movement immediately suspended its campaign. Millicent Fawcett and Emmeline Pankhurst urged their followers to do what they could for the war effort. In July 1915, Emmeline Pankhurst launched the "Right to Serve" campaign out of growing frustration at the government's reluctance to organize substitution (the replacement of men by women). The campaign proved to be decisive as women massively entered vital war work (Sue BRULEY, Women in Britain Since 1900, Basingstoke: Palgrave Macmillan, 1999, p. 39). 
8. When offering her services in August 1914, the founder of the Scottish Women's Hospitals, Dr Elsie Inglis, had been offensively rebuffed by the War office with the words "My good lady, go home and sit still." With the help of the Scottish branch of the National Union of Women's Suffrage Societies, she set up the main French base at the Abbaye de Royaumont in December (Anne POWELL, Women in the War Zone, Hospital Service in the First World War, Stroud: The History Press, 2013, p. 15).

For a first-hand account of the SWH at the Abbey of Royaumont, see Antonio de NAVARRO, The Scottish Women's Hospital at the French Abbey of Royaumont, London: George Allen and Unwin, first published in 1917, digitized in 2007 by the Internet Archive, https://archive.org/details/ scottishwomensho00navauoft, [Last accessed 23 May 2014].

9. On 25 August 1944, while Paris was being liberated, Maillé (Indre-et-Loire) was razed to the ground by the German army. 124 people, including 44 children were killed. Several tons of clothes, furniture and food were sent to the population of Maillé by Kathleen Burke and her husband, Girard Hale, until their deaths in 1958 (Sébastien CHEVEREAU, dossier de presse "De Santa Barbara à Maillé”, Maison du souvenir de Maillé, maison-du-souvenir@maille.fr, http:// www.cndp.fr/crdp-orleans-tours/images/stories/CDDP37/dossier\%20de\%20presse\%20hale.pdf [ Last accessed 23 May 2014], p. 18).

Kathleen Burke also wrote on children during World War One: Little Heroes of France, Doubleday, Page and Company, 1920, 223 p. and Young Heroes of Britain and Belgium, Doubleday, Page and Company, 1921, $289 \mathrm{p}$.

10. Official censorship was enforced through the Defence of the Realm Act (DORA) passed in August 1914. Front-line reporting was first banned, then closely controlled by the War office. Publications were filtered and private mails read. By early 1917, there were about 5,200 British censors employed to screen front-line news. (Spencer TUCKER (ed.), The European Powers in the First World War: An Encyclopedia, London: Routledge, 1999, pp178-179).

11. Sébastien CHEVEREAU, op. cit., p.12.

12. Jack Edward McCALLUM, Military Medicine: From Ancient Times to the 21st Century, Santa Barbara: Abc-Clio, 2007, p.60.

13. Christine HALLETT, op. cit., p. 48.

14. Winifred Lilian KENYON, op. cit., p.6.

15. Janet LEE, War Girls: The First Aid Nursing Yeomanry in the First World War, Manchester: Manchester University Press, 2005, p. 11.

16. Winifred Lilian KENYON, op. cit., p. 20.

Christine Hallett mentions that, as opposed to trained nurses, VADs frequently commented on the "routinisation of ward work, which many felt was taken to the point of unnecessary regimentation", Christine HALLETT, op. cit., p. 48.

17. J.A.C.F. [presumably Chief Medical Officer CAIRNS FORSYTH], «A Short History of the Urgency Cases Hospital », Le Faux Miroir, January 1917, p. 14. Found in Miss Kenyon's personal papers.

18. Ibid.

19. Gas was highly destructive and was first introduced at Ypres in April 1915, Christine HALLETT ,op. cit., p. 59.

20. Winifred KENYON, op. cit., p. 21

21. Christine HALLETT, op. cit., p. 158.

22. Ruth COWEN (ed.), War Diaries, a Nurse at the Front, The First World War Diaries of Sister Edith Appleton, London: Simon \& Schuster, 2012, p. 81-82.

23. Gerald BOWMAN, The Lamp and the Book: the Story of the Rcn, 1916-1966, London : Queen Ann P., 1967, p. 65. [The RCN is the Royal College of Nursing]

24. Article 1 of the Convention for the Amelioration of the Wounded in Armies in the Field (22 August 1864) states "Ambulances and military hospitals shall be recognized as neutral, and as such, 
protected and respected by the belligerents as long as they accommodate wounded and sick. Neutrality shall end if the said ambulances or hospitals should be held by a military force." (International Committee of the Red Cross, http://www.icrc.org/applic/ihl/ihl.nsf/ART/120-40001? OpenDocument, [Last accessed 30 May 2014]).

25. Winifred KENYON, op. cit., p. 35.

26. Ibid.

27. Ibid., p. 37.

28. http://www.wereldoorlog1418.nl/battleverdun/battleverdun22/index.htm, [Last accessed 23 May 2014].

Over the course of the battle of Verdun (21 February 1916 - 19 December 1916), about 163,000 Frenchmen and 143,000 Germans died or were reported missing. About 216,000 Frenchmen and 196,000 Germans were injured (http://eng.verdun.fr/Universal-city/Verdun-and-World-War-I/ The-Battle-of-Verdun, [Last accessed 23 May 2014]).

29. Winifred KENYON, op.cit, p. 38.

30. Ibid.

31. Ibid., p. 39.

32. Ibid., p. 40

33. Ibid., p. 16.

34. A. COHEN, S. GILMAN, J. BORDO \& R. SMITH, On European Ground, Chicago: Chicago University Press, 2001, p. 120.

35. Christine HALLETT, op. cit., p. 8

36. Janet LEE, op. cit., p. 11

37. Winifred KENYON, op. cit., p. 37.

38. Ibid. p. 3

39. Ibid.

40. Christine HALLETT, op. cit., p. 226

41. The book was published just a few months after her mission by Hodder and Stoughton, a publishing house which worked closely with the War Propaganda Bureau headed by Charles Masterman. Other leading publishing companies commissioned by the Bureau to promote the nation's interests included Methuen, Oxford University Press or Macmillan (http:// www.spartacus.schoolnet.co.uk/FWWwpb.htm\#, [Last accessed 23 May 2014] and N. J. CULL, D. CULBERT \& D. WELCH, Propaganda and Mass Persuasion: a Historical Encyclopedia, 1500 to the present, Santa Barbara: ABC-Clio, 2003, p. 152).

42. Peter BUITENHUIS, loc. cit., p. 13.

43. Kathleen BURKE, op. cit., p. 30.

44. Erich Maria Remarque's All Quiet on the Western Front and other works written by combatants during or shortly after the war give the reader an insight into this spirit of comradeship. They also cast light on the exclusive nature of the bond that united combatants or veterans, a bond that only those who had endured combat and life in the trenches could experience and share. In his analysis on the reluctance of many soldiers to talk about the war, Julian Walkers has identified the sense of "belonging at the front" as one of the reasons for this failure to communicate with non-combatants. Thus, for Robert Graves, "Home was awful because you were with people who didn't understand what it was all about." (Julian Walkers, "The silence after the war", The British Library, http://www.bl.uk/world-war-one/articles/the-silence-after-the-war, [Last accessed 30 May 2014]).

45. Kathleen BURKE, op. cit., p. 24.

46. Ibid., p. 12.

47. S. M. EDWARDS, “Thoughts of a Night Sister”, Le Faux Miroir, January 1917, p.17. The original copy is included in Winifred Kenyon's private papers (documents.374, catalogue date 1990-05, Imperial War Museum). 
48. Christine HALLETT, op. cit., p. 49

49. W. KENYON, op.cit., p. 52

50. Ibid., p. 177-178.

51. Letter from Katharine FURSE, B.R.C.S., the Commandant-in-Chief, Women's Voluntary Aid Detachment, to serving VAD nurses (1914), http://www.spartacus.schoolnet.co.uk/ FWWnurses.htm, [Last accessed 23 May 2014].

52. Katie HOLMES, "Day Mothers, Night Sisters: World War One Nurses and Sexuality", in J. DAMOUSI \& M. LAKE (ed.), Gender and War: Australians at war in the Twentieth Century, Cambridge: Cambridge University Press, 1995, p. 52.

\section{ABSTRACTS}

This paper focuses on the experience of British nurses, drawing on the personal accounts of $\mathrm{K}$. Burke, W. Kenyon and S.M. Edwards, three British women posted on the Verdun front. Though acting at different levels of responsibility, these young volunteers went through converging experiences. Trying to put down in words this unspeakable reality, their eyewitness accounts echo one another. This paper will first address military and historical aspects as developed by Kenyon and Burke. It will then explore the social dimension of these accounts, reflecting on the significance of early $20^{\text {th }}$ century social representations and wartime expectations. Propaganda, its distortion of motherhood and its instrumentalisation of femininity and masculinity will also be developed. This paper will finally analyse the nurses' focus on compassion and the domestic image attached to nursing.

Cet article s'articule autour des expériences de K. Burke, W. Kenyon et S. M. Edwards, trois infirmières britanniques engagées sur le front de Verdun. Bien qu'étant intervenues à différents niveaux de responsabilité, ces trois femmes ont vécu des expériences convergentes et leur parcours s'inscrit dans une action commune. Toutes ont laissé des témoignages très riches sur le siège et la bataille de Verdun. En tentant de mettre des mots sur cette innommable réalité, leurs récits entrent en résonnance, tout en offrant un éclairage sur le poids des représentations sociales, notamment des rôles sociaux sexués de l'époque et l'impact de la propagande, qu'elle soit intériorisée ou relayée et que les femmes en soient destinatrices ou destinataires. Indissociables de l'esprit et des valeurs de ce début de 20 ème siècle, ces récits mettent également en lumière l'esprit de compassion lié à l'infirmière de la Grande guerre.

\section{INDEX}

Mots-clés: Première Guerre mondiale, infirmières, représentations sociales, propagande, genre

Keywords: World War One, nursing, social representations, propaganda, gender

\section{AUTHOR}

\section{SYLVIE POMIÈS-MARÉCHAL}

ESPE Centre Val de Loire, Université d'Orléans 